Sains Malaysiana 49(7)(2020): 1615-1625

http://dx.doi.org/10.17576/jsm-2020-4907-13

\title{
Secondhand Smoke Exposure and Autism Spectrum Disorder: A Meta-analysis
}

(Pendedahan Asap Rokok Sekunder dan Gangguan Spektrum Autisme: Suatu Analisis Meta)

\author{
Fadzrul Hafiz Johani, Nur Ezdiani Mohamed, Mohd Shafik Abd Majid, Siti Diyana Ibrahim \& Zaleha \\ MD ISA*
}

\begin{abstract}
Nicotine exposure during early life can significantly affect neurocognitive development. This meta-analysis was conducted to explore whether an association exists between secondhand smoke (SHS) exposure and risk of autism spectrum disorder (ASD) in children. Database search using PubMed, SAGE, Scopus, ScienceDirect, ProQuest, and Google Scholar were used to search observational studies from January 2009 until January 2020. The random-effect model was used to combine results from individual studies. Four studies (2 cross-sectional studies, 1 case-control study, and 1 mixed design study) with 2,434 ASD cases and a total of 104,128 participants were included in the analysis. The pooled odds ratio (OR) was 1.36 (95\% confidence interval (CI): 1.25-1.49) comparing SHS exposure in children with those who were not exposed. Heterogeneity was not significant across studies $\left(C h i^{2}=0.41, p=0.94, I^{2}=0 \%\right)$. Results from this meta-analysis indicated that SHS exposure has significant association with risk of ASD in children. Current findings should be confirmed through more studies including prospective cohort studies.
\end{abstract}

Keywords: Autism spectrum disorder; children; meta-analysis; secondhand smoke

ABSTRAK

Pendedahan nikotin semasa usia muda boleh menjejaskan perkembangan neurokognitif. Analisis meta ini dijalankan untuk mengkaji sama ada wujud hubungan antara pendedahan asap rokok sekunder (SHS) dengan risiko gangguan spektrum autisme (ASD) pada kanak-kanak. Carian melalui pangkalan data PubMed, SAGE, Scopus, ScienceDirect, ProQuest dan Google Scholar digunakan untuk mencari kajian pengamatan dari Januari 2009 sehingga Januari 2020. Model kesan-rawak digunakan untuk menggabungkan keputusan daripada setiap kajian. Empat kajian (2 kajian keratan rentas, 1 kajian kawalan kes dan 1 kajian reka bentuk campuran) dengan 2,434 kes ASD dan sejumlah 104,128 peserta dimasukkan ke dalam analisis. Nisbah ods terkumpul adalah 1.36 (95\% selang keyakinan: 1.25-1.49) yang membandingkan pendedahan SHS pada kanak-kanak dengan mereka yang tidak terdedah. Keheterogenan adalah tidak bererti antara kajian (Chi ${ }^{2}=0.41, p=0.94, I^{2}=0 \%$ ). Keputusan daripada analisis meta ini menunjukan bahawa SHS mempunyai hubung kait yang bererti dengan risiko ASD pada kanak-kanak. Penemuan ini perlu disahkan menerusi lebih banyak kajian termasuk kajian kohort prospektif.

Kata kunci: Analisis meta; asap rokok sekunder; gangguan spektrum autisme; kanak-kanak

\section{INTRODUCTION}

Autism spectrum disorder (ASD) refers to a range of complex neurodevelopmental disorder that impairs an individual's social interaction and communication and have repetitive behavior (Copeland 2018; WHO 2017). The prevalence of ASD has increased markedly in recent decades, resulting in substantial public concern and increased level of ASD surveillance and research (Barnevik-Olsson et al. 2010; Kim et al. 2011; Matson \& Kozlowski 2011; Pinborough-Zimmerman et al. 2012). The reported prevalence of ASD varies substantially across studies and appears to be increasing worldwide (Baio et al. 2018; Christensen et al. 2016; Kim et al. 2011; Samadi et al. 2012; Sun et al. 2013; WHO 2017). Globally, it is estimated that 1 in 160 children has an ASDs (WHO 2017).

The aetiology of ASD remains unclear. Current available scientific evidences suggest that there are possibly many factors that make a child more likely to have an ASD, and environmental and genetic factors are thought to play an important role (Abrahams \& Geschwind 2010; Chaste \& Leboyer 2012; Grabrucker 2013; Landrigan 2010; WHO 2017). Environmental factors associated with ASD include various types of chemicals such as lead, mercury, industrial paint, and organochloride pesticides (Blaurock-Busch et al. 2011; Symeonides et al. 2013) which can also be found in cigarette smoke (ALA 2016). These environmental risk 
factors had garnered interest in the study of tobacco smoke exposure association with ASD (Jung et al. 2017; Rosen et al. 2015; Tang et al. 2015).

Exposure to a complex mixture of gases and particles breathed out by smokers or smoke from burning tobacco products such as cigarettes, cigar, or pipes is known as secondhand smoke (SHS) or environmental tobacco smoke (Group 2006). Exposure to SHS can occur as early as prenatal period and anywhere, such as at home and in public places. Children are more susceptible to SHS at home (Physicians 2010) from one or both smoking parents or living with anyone who is a smoker. They are known to be a vulnerable group to the SHS adverse health effects (Health \& Services 2006; Jarvis et al. 2012; Mbulo et al. 2016). One study in 2004 showed that about $40 \%$ of children were exposed to SHS in any environment (Öberg et al. 2011).

Many studies are investigating the association between maternal smoking during pregnancy and risk of ASD, but four previous meta-analysis failed to prove significant association (Gardener et al. 2009; Jung et al. 2017; Rosen et al. 2015; Tang et al. 2015). However, there are studies showing that early life exposure to SHS can cause adverse neurodevelopmental effects in children (Chastang et al. 2015; Eskenazi \& Castorina 1999; Mohamed et al. 2018; Yolton et al. 2004). This is because postnatal SHS may be more hazardous to developing brain as compared to SHS in utero (Kalkbrenner et al. 2014; Rice \& Barone Jr. 2000) as inhalation exposure provides a higher dose than transplacental exposure (Eskenazi \& Castorina 1999; Rebagliato et al. 1998). In addition, longer duration of exposure during childhood compared to the foetus may be the critical factor for the neurodevelopmental effect of SHS (Eskenazi \& Castorina 1999). This biological plausibility was supported in an animal experiment where Gospe Jr. et al. (1996) noted that a rat's brain development was altered by postnatal but not prenatal exposure to SHS.

Studies also showed that SHS exposures were approximates of male smoking prevalence, thus paternal or postnatal tobacco smoke exposure and its association with ASD are substantial to be explored (Jung et al. 2017; Tiesler et al. 2011). Thus, the goal of this study was to review current available evidences to determine the association between postnatal SHS exposure and risk of ASD in children.

\section{METHODS}

\section{DATA SOURCES AND SEARCHES}

This meta-analysis was performed based on the PRISMA statement. The search was performed on various databases available in institutional subscriptions: PubMed, SAGE, Scopus, ScienceDirect, ProQuest, and
Google Scholar. The search strategy followed the PICO framework. The search terms used were: ('secondhand smoke' OR 'passive smoking' OR 'environmental tobacco smoke' OR 'involuntary smoking' OR 'tobacco smoke exposure' OR 'paternal smoke exposure' OR 'parental smoke exposure' OR 'maternal smoke exposure') and ('Autism' OR 'Autism spectrum disorder' OR 'Autism disorder'). The search was restricted to studies conducted in the past 11 years, from 2009 to January 2020 inclusive of any theses and dissertations found. English language restriction was applied in the process of literature search and selection.

\section{STUDY SELECTION}

The reviewing process was conducted in two parts by two pairs of reviewers. In the first part, a pair of reviewers independently screened the titles and abstracts for the potential article to be included in the study. Studies were included if they met the following criteria: observational studies; specific outcome measured; exposure to tobacco smoke; children age up to 18 years old; exclude prenatal tobacco smoke exposure; exclude animal studies, reviews, letters, conference abstracts, case reports, or studies that have insufficient information. In the second part, the full-text articles were retrieved, and another pair of reviewers independently screened the full-text articles for a detailed review to select the articles. Any disagreement will be solved by the third reviewer.

\section{DATA EXTRACTION AND QUALITY ASSESSMENT}

Two pairs of reviewers independently extracted the data from selected articles. Any disagreements were resolved by discussion between reviewers. The data were extracted using a standardized form to include publication year, study location, country, study design, sample size, demographic characteristics, SHS exposure assessment method, laboratory results of exposure, ASD status assessment method, main outcome, unadjusted, and adjusted OR with 95\% CI, p-value, and adjustment for confounders.

The quality of selected articles was assessed by two authors independently using the NewcastleOttawa Quality Assessment Scale (NOS) to examine for concordance and averaged for each study. The NOS has been widely used for quality assessment of observational studies (Modesti et al. 2016; Stang 2010). NOS evaluates three components to quantify study quality i.e. selection of study subjects, comparability of study groups, and exposure or outcome ascertainment which consists of eight items with a maximum of nine scores for each item. The scores of each item indicate methodological quality of the study. The study was categorised into high, moderate, or low quality based on the total score of 7-9, 4-6, 0-3, respectively (Tang et al. 2015). 


\section{DATA ANALYSIS}

The association between ASD and SHS exposure was measured by combining the OR in each study. The random-effect model was used in the meta-analysis to calculate the pooled OR. The Chi-squared $\left(\chi^{2}\right)$ and $\mathrm{I}^{2}$ value were used to determine heterogeneity of the studies, calculated using Review Manager Ver5.3. Subgroup and sensitivity analysis were performed if $\mathrm{p}<0.1$ and $\mathrm{I}^{2}$ value $\geq 50 \%$.

\section{RESULTS}

\section{LITERATURE SEARCH AND STUDY SELECTION}

The search strategy yielded 652 literatures. A total of 594 articles were left for screening following removal of duplicate literatures. Screening of the remaining titles and abstracts excluded another 468 studies which were not relevant to the study objective and involved animal studies. The remaining literatures were retrieved to be assessed for eligibility and detailed evaluation which further excluded 122 studies. The reasons for exclusion included no outcome measured, the studies looked at different exposures such as heavy metal, the studies looked for association with different outcomes such as behavioral outcome, and the studies measured association between prenatal exposure of tobacco smoke and ASD instead of postnatal exposure. Four remaining articles (Kaur 2014; Khalil et al. 2018; Kim et al. 2018; Larsson et al. 2009) were included for the meta-analysis. Figure 1 shows the flow diagram of the selection process according to PRISMA flow diagram (Moher et al. 2009).

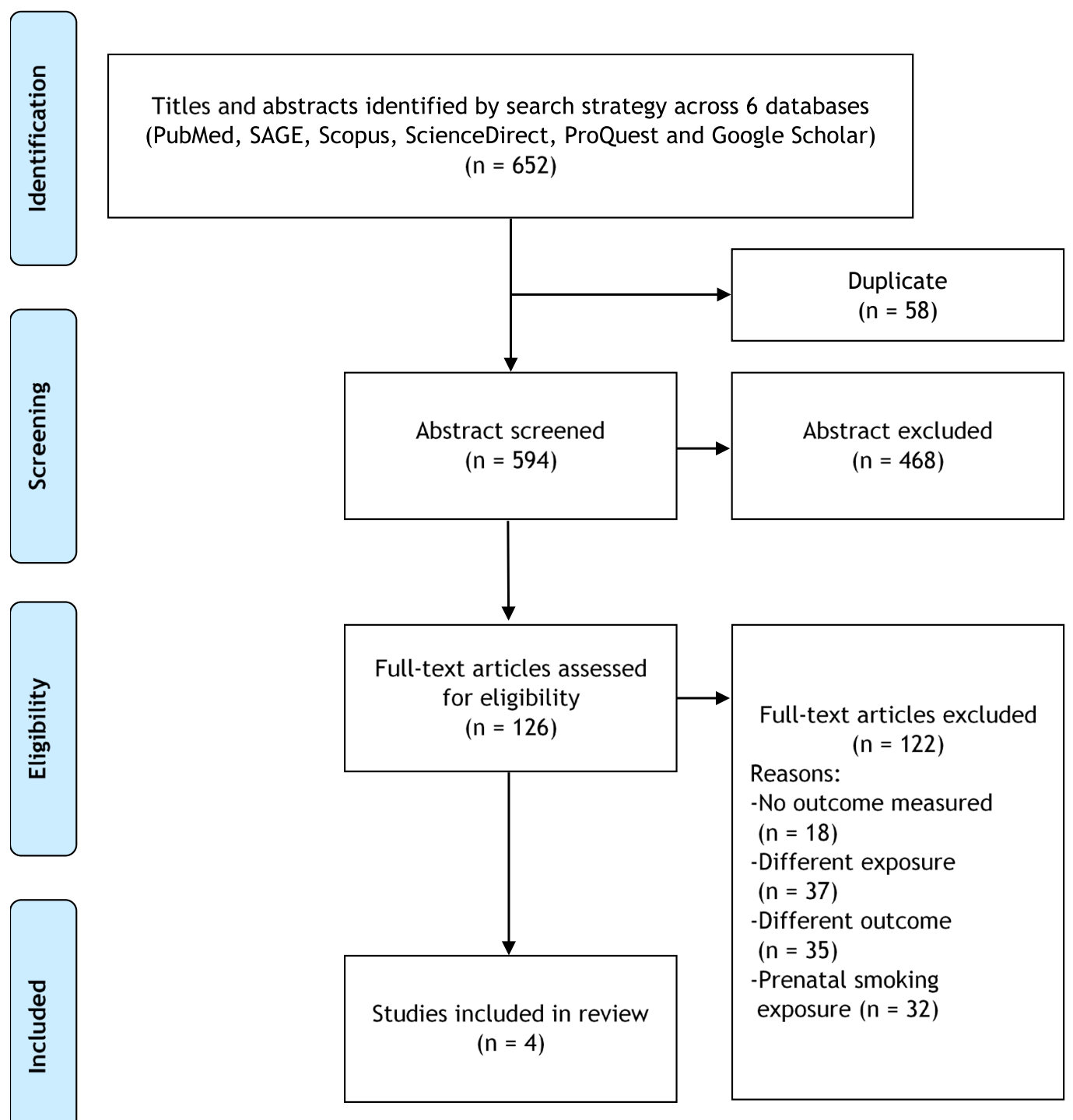

FIGURE 1. PRISMA flow diagram 


\section{STUDY CHARACTERISTICS}

Table 1 lists the characteristics of the included studies. Of the four selected studies, one had three study designs combined and executed in three phases which were cross sectional, nested case-control, and cohort (Larsson et al. 2009). Two studies were cross-sectional (Kaur 2014; Khalil et al. 2018) and one was case-control (Kim et al. 2018). The study with three phases involved participants ranging from 400 to 14,077 ; the case-control had 67 cases, while the cross-sectional studies had up to 56,710 participants. The two latter studies were taken from the same pool of participants and carried out in the USA, the case-control study was done in Korea, while the last one was done in Sweden. SHS exposure assessment method was either through biochemical test (urinary cotinine) (Kim et al. 2018) or based on participants' response to questions asked (Kaur 2014; Khalil et al. 2018; Larsson et al. 2009). For urinary cotinine, exposure was confirmed based on the urinary cotinine levels with mean concentration (standard deviation) of urinary cotinine in the normal control and ASD groups of 2.53 $\mathrm{ng} / \mathrm{mL}$ (7.20) and $6.02 \mathrm{ng} / \mathrm{mL}$ (11.13), respectively. For those who used the questionnaire, confirmation on SHS exposure was based on the positive response 'yes' by the respondents/proxy answering the questions. ASD status was ascertained either through screening followed by a diagnosis by a psychiatrist (Kim et al. 2018) or based on participants' response to questions asked (Kaur 2014; Khalil et al. 2018; Larsson et al. 2009).

\section{EVALUATION OF QUALITY OF STUDIES}

Two authors independently assigned Newcastle-OttawaScale (NOS) scores to each study. The correlation coefficient scores between two authors were strong ( $\mathrm{r}$ $(4)=0.87$ ) (Figure 2). Overall, the study had moderate methodological quality as scored on NOS, with a mean score of 7.0 and a range of 5.5-9.0. One study was considered high quality with a NOS score of 9.0 (Kim et al. 2018) and three studies were considered moderate quality with NOS scores within a range of 4.0-6.0 (Kaur 2014; Khalil et al. 2018; Larsson et al. 2009) (Supplemental Table 1).

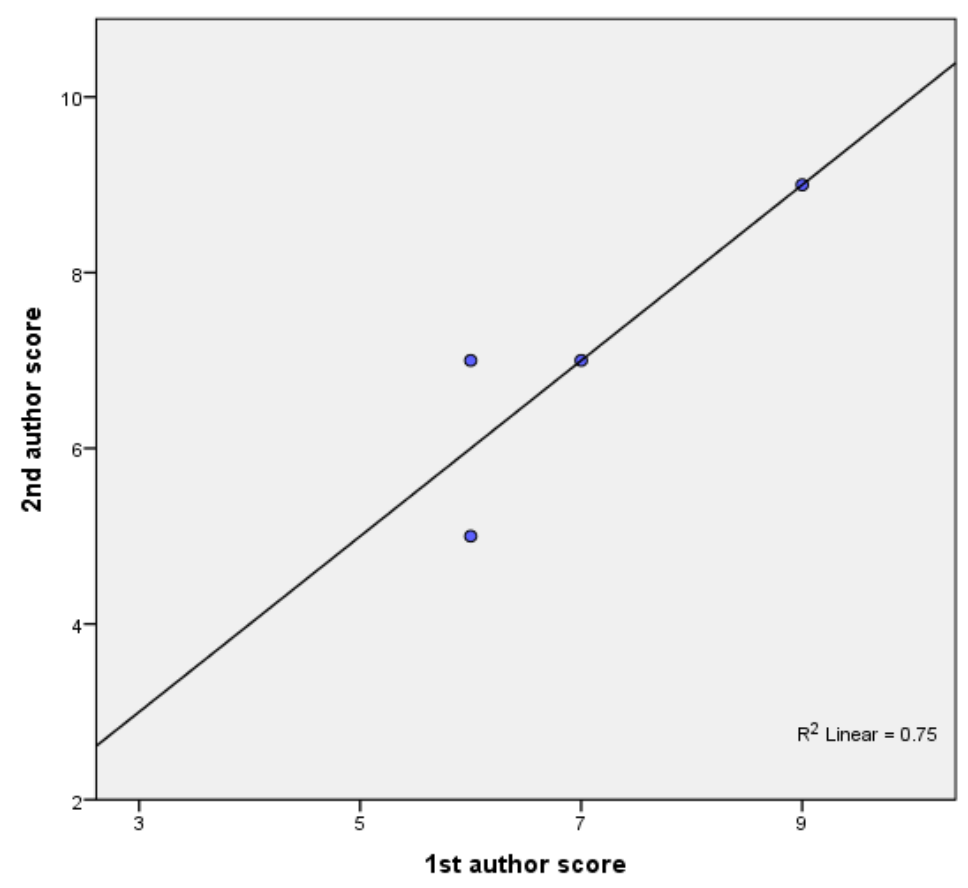

FIGURE 2. Quality assessment of individual studies using NOS by two independent authors

\section{PUBLICATION BIAS}

The shape and symmetry of the funnel plot of log ORs from the four studies, as shown in Figure 3, suggested the presence of publication bias. 


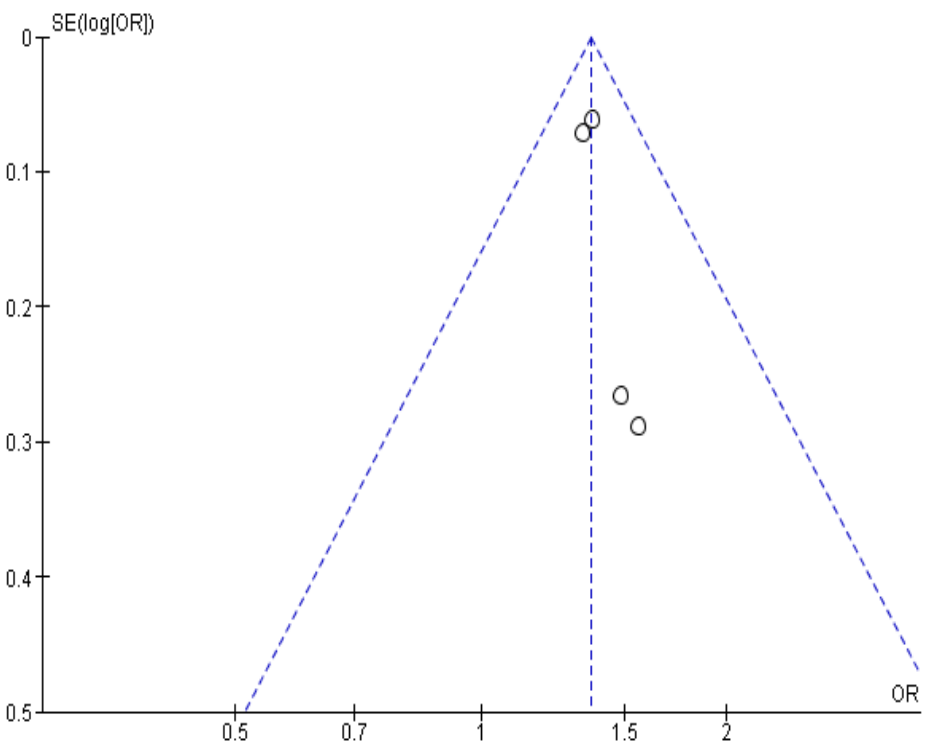

FIGURE 3. Funnel plot of the four studies included in the meta-analysis

TABLE 1. Characteristic of the studies

\begin{tabular}{|c|c|c|c|c|c|c|c|c|c|c|}
\hline $\begin{array}{l}\text { Author; } \\
\text { Year; } \\
\text { Location }\end{array}$ & $\begin{array}{l}\text { Study } \\
\text { Design }\end{array}$ & Sample Size & $\begin{array}{c}\text { Participant } \\
\text { Characteristic }\end{array}$ & $\begin{array}{l}\text { SHS assessment } \\
\text { method }\end{array}$ & $\begin{array}{l}\text { Laboratory } \\
\text { Results of } \\
\text { Exposure }\end{array}$ & $\begin{array}{l}\text { ASD status } \\
\text { assessment } \\
\text { method }\end{array}$ & Main outcome & $\begin{array}{l}\text { Odds Ratio } \\
(95 \% \mathrm{CI})\end{array}$ & $\begin{array}{l}\text { Adjustments } \\
\text { for confounders }\end{array}$ & Conclusion \\
\hline $\begin{array}{l}\text { Kim } \\
\text { et al. } \\
(2018) \\
\text { Korea }\end{array}$ & $\begin{array}{l}\text { Case- } \\
\text { control } \\
\text { study }\end{array}$ & $\begin{array}{c}67 \text { cases } \\
253 \text { controls }\end{array}$ & $\begin{array}{c}\text { Mean }(\mathrm{SD}) \\
\text { age: } \\
8.15(1.22) \\
\text { years } \\
\\
\text { Gender: } \\
\text { Male: } 54 \\
(80.6 \%) \\
\text { Female: } 13 \\
(19.4 \%)\end{array}$ & $\begin{array}{l}\text { Measured using } \\
\text { urinary cotinine } \\
\text { level }\end{array}$ & $\begin{array}{c}\text { Mean } \\
\text { concentration } \\
\text { (SD) of } \\
\text { urinary } \\
\text { cotinine: } \\
\text { Control } \\
\text { group: } \\
2.53 \mathrm{ng} / \mathrm{mL} \\
\text { (7.20) } \\
\text { ASD group: } \\
6.02 \mathrm{ng} / \mathrm{mL} \\
(11.13)\end{array}$ & $\begin{array}{l}\text { Screening using } \\
\text { Autism } \\
\text { Spectrum } \\
\text { Screening } \\
\text { Questionnaire } \\
\text { (ASSQ) } \\
\text { followed by } \\
\text { a psychiatrist } \\
\text { diagnosis using } \\
\text { diagnostic } \\
\text { interview }\end{array}$ & $\begin{array}{l}\text { Association } \\
\text { between } \\
\text { urinary } \\
\text { cotinine } \\
\text { levels and } \\
\text { ASD }\end{array}$ & $\begin{array}{l}\text { OR: } 1.89 \\
(1.12-3.21)\end{array}$ & $\begin{array}{l}\text { Age, sex, } \\
\text { parent } \\
\text { educational } \\
\text { level, } \\
\text { household } \\
\text { income }\end{array}$ & $\begin{array}{c}\text { Higher } \\
\text { urinary } \\
\text { cotinine } \\
\text { levels were } \\
\text { positively } \\
\text { associated } \\
\text { with ASD }\end{array}$ \\
\hline $\begin{array}{l}\text { Larsson } \\
\text { et al. } \\
\text { (2009) } \\
\text { Sweden }\end{array}$ & $\begin{array}{c}\text { Phase 1: } \\
\text { Cross } \\
\text { sectional } \\
\text { Phase 2: } \\
\text { Nested } \\
\text { case- } \\
\text { control } \\
\text { Phase 3: } \\
5 \text { years } \\
\text { follow- } \\
\text { up }\end{array}$ & $\begin{array}{c}\text { Phase 1: } \\
\text { 10,851/ } \\
14,077 \\
(79 \%) \\
\text { Phase 2: } 198 \\
\text { symptoms, } \\
\text { 202 healthy } \\
\text { (400) } \\
\text { Phase 3: } \\
\text { 5,483/7,509 } \\
\text { (73\%) } \\
\text { Total Phase } \\
\text { 1 and 3: } \\
\text { 4,779 }\end{array}$ & $\begin{array}{c}\text { Age: } \\
\text { Phase 1: } 1 \text { - } 6 \\
\text { years } \\
\text { Phase 2: } 1 \text { - } 6 \\
\text { years } \\
\text { Phase 3: } \\
\text { (Follow up } \\
\text { after 5 years) } \\
\text {-6 years, } \\
\text { n=1,557 } \\
(32.6 \%) \\
-7 \text { years, } \\
\text { n=1,568 } \\
(32.8 \%) \\
-8 \text { years, } \\
\text { n=1,654 } \\
(34.6 \%) \\
\\
\text { Gender at } \\
\text { Phase } 3: \\
\text { Male: } 2,388 \\
(50 \%) \\
\text { Female: } 2,391 \\
(50 \%)\end{array}$ & $\begin{array}{l}\text { Questions asking } \\
\text { anyone smoking } \\
\text { in family or } \\
\text { smoking during } \\
\text { first year }\end{array}$ & NA & $\begin{array}{l}\text { Parent Report in } \\
\text { questionnaire }\end{array}$ & $\begin{array}{l}\text { Associations } \\
\text { between } \\
\text { amily } \\
\text { structure, } \\
\text { specified } \\
\text { family } \\
\text { behaviors, } \\
\text { environmental } \\
\text { and } \\
\text { socioeconomic } \\
\text { factors and ASD }\end{array}$ & $\begin{array}{l}\text { Smoking in } \\
\text { family } \\
1 . \text { Any } \\
\text { smoker in } \\
\text { family: } \\
\text { OR: } 1.49 \\
(0.89-2.48) \\
\text { 2. Smoking } \\
\text { mother: } \\
\text { OR: } 2.06 \\
\text { (1.20-3.53) } \\
\text { 3. Smoking } \\
\text { father: } \\
\text { OR: } 1.75 \\
(0.94-3.28) \\
\text { Smoking } \\
\text { during first } \\
\text { year } \\
\text { Mother: } \\
\text { OR: } 2.09 \\
\text { (1.17-3.72) } \\
\text { Father: } \\
\text { OR: } 1.66 \\
\text { (0.88-3.13) } \\
\text { Mother } \\
\text { Smoking: } \\
\text { AOR: } 1.79 \\
\text { (1.02-3.13) }\end{array}$ & $\begin{array}{c}\text { Sex, age, } \\
\text { asthma, } \\
\text { low ventilation, } \\
\text { type of flooring }\end{array}$ & $\begin{array}{l}\text { The study } \\
\text { confirmed } \\
\text { that } \\
\text { smoking } \\
\text { during the } \\
\text { child's } \\
\text { first year } \\
\text { of life can } \\
\text { be coupled } \\
\text { with ASD }\end{array}$ \\
\hline
\end{tabular}




\begin{tabular}{|c|c|c|c|c|c|c|c|c|c|c|}
\hline $\begin{array}{l}\text { Kaur } \\
(2014) \\
\text { United } \\
\text { States }\end{array}$ & $\begin{array}{l}\text { Cross } \\
\text { sectional } \\
\text { study }\end{array}$ & 43,418 & $\begin{array}{c}\text { Mean age of } \\
\text { children who } \\
\text { suffered from } \\
\text { ASD was } 6.5 \\
\text { years } \\
\\
\text { Gender: } \\
\text { Male: } 22,151 \\
(51 \%) \\
\text { Female: } 21,268 \\
(49 \%)\end{array}$ & $\begin{array}{l}\text { Random } \\
\text { telephone } \\
\text { survey through } \\
\text { questions, } \\
\text { "Does anyone } \\
\text { living in your } \\
\text { household } \\
\text { use cigarettes, } \\
\text { cigars or pipe } \\
\text { tobacco"? and } \\
\text { "Does anyone } \\
\text { smoke inside } \\
\text { child's home"? }\end{array}$ & NA & $\begin{array}{l}\text { Questionnaires: } \\
\text { "Does the } \\
\text { child currently } \\
\text { have autism, } \\
\text { Asperger's } \\
\text { disorder, } \\
\text { childhood } \\
\text { pervasive } \\
\text { development } \\
\text { disorder, or } \\
\text { other autism } \\
\text { spectrum } \\
\text { disorder?" }\end{array}$ & $\begin{array}{c}\text { Association } \\
\text { between SHS } \\
\text { exposure and } \\
\text { ASD }\end{array}$ & $\begin{array}{c}\text { (Yes, not } \\
\text { inside } \\
\text { house) } \\
\text { OR: } 1.36 \\
(1.17-1.58) \\
\text { AOR: } 1.14 \\
(0.98-1.33) \\
\text { (Yes, inside } \\
\text { house) } \\
\text { OR: } 1.39 \\
(1.03-1.88) \\
\text { AOR: } 0.89 \\
(0.65-1.21)\end{array}$ & $\begin{array}{l}\text { Age, gender, } \\
\text { race/ethnicity, } \\
\text { socioeconomic } \\
\text { status, mother's } \\
\text { mental status, } \\
\text { birth weight, } \\
\text { primary } \\
\text { language }\end{array}$ & $\begin{array}{c}\text { SHS } \\
\text { exposure } \\
\text { is not } \\
\text { significantly } \\
\text { associated } \\
\text { with } \\
\text { ASDs }\end{array}$ \\
\hline $\begin{array}{l}\text { Khalil } \\
\text { et al. } \\
\text { (2018) } \\
\text { United } \\
\text { States }\end{array}$ & $\begin{array}{c}\text { Cross } \\
\text { sectional } \\
\text { study }\end{array}$ & 56,710 & $\begin{array}{c}\text { Mean (SD) } \\
\text { age: } \\
7.08 \pm 0.03 \\
\text { years } \\
\\
\text { Gender: } \\
\text { Male: } 28978 \\
(51.1 \%) \\
\text { Female: } 27732 \\
(48.9 \%)\end{array}$ & $\begin{array}{l}\text { Questionnaire } \\
\text { by random } \\
\text { telephone, "Does } \\
\text { anyone living in } \\
\text { your household } \\
\text { use cigarettes, } \\
\text { cigars, or } \\
\text { pipe tobacco?" }\end{array}$ & NA & $\begin{array}{l}\text { Questionnaire: } \\
\text { "Does the } \\
\text { child currently } \\
\text { have autism, } \\
\text { Asperger's } \\
\text { disorder, } \\
\text { childhood } \\
\text { pervasive } \\
\text { development } \\
\text { disorder, or } \\
\text { other ASD?" }\end{array}$ & $\begin{array}{c}\text { Association } \\
\text { between SHS } \\
\text { exposure and } \\
\text { ASD }\end{array}$ & $\begin{array}{c}\text { OR: } 1.36 \\
(1.04-1.78) \\
\text { AOR: } 1.28 \\
(0.95-1.73)\end{array}$ & $\begin{array}{c}\text { Male, age, } \\
\text { maternal age, } \\
\text { maternal } \\
\text { mental status, } \\
\text { mother's } \\
\text { education, } \\
\text { socioeconomic } \\
\text { status }\end{array}$ & $\begin{array}{l}\text { SHS is } \\
\text { significantly } \\
\text { associated } \\
\text { with ASD } \\
\text { in male } \\
\text { children }\end{array}$ \\
\hline
\end{tabular}

\section{MAIN ANALYSIS}

The meta-analysis data using random-effect model to explore the effect of SHS on the risk of ASD in children are shown in Figure 4. The forest plot illustrates the spread of the four studies' risk estimates and their confidence intervals in relation to the summary OR of meta-analysis. The $\mathrm{Chi}^{2}$ for the random-effect meta-analysis that tested for equal variance between studies had a value of 0.41 $(p=0.94)$ which indicates that there was homogeneity between studies. $\mathrm{I}^{2}$ index which indicates the level of heterogeneity was estimated to be $0 \%$. Based on the four studies, the pooled OR estimates showed that SHS exposure was significantly associated with an increased risk of ASD (OR $=1.36 ; 95 \%$ CI: 1.25-1.49).

\begin{tabular}{|c|c|c|c|c|c|c|c|c|}
\hline \multirow[b]{2}{*}{ Study or Subgroup } & \multicolumn{2}{|c|}{ SHS Exposure } & \multicolumn{2}{|c|}{ Control } & \multicolumn{2}{|r|}{ Odds Ratio } & \multirow{2}{*}{\multicolumn{2}{|c|}{$\begin{array}{c}\text { Odds Ratio } \\
\text { M.H, Random, } 95 \% \mathrm{Cl}\end{array}$}} \\
\hline & Events & Total & Events & Total & Weight & M-H, Random, $95 \% \mathrm{Cl}$ Year & & \\
\hline Larsson et al. 2009 & 20 & 1009 & 52 & 3870 & $2.9 \%$ & $1.48[0.88,2.50] 2009$ & & \\
\hline Kaur 2014 & 276 & 9860 & 694 & 32864 & $39.6 \%$ & $1.33[1.16,1.54] 2014$ & & $\rightarrow-$ \\
\hline Kim et al. 2018 & 26 & 100 & 39 & 212 & $2.5 \%$ & $1.56[0.88,2.74] 2018$ & & \\
\hline Khalil et al. 2018 & 389 & 13134 & 938 & 43079 & $55.0 \%$ & $1.37[1.22,1.55] 2018$ & & -1 \\
\hline Total $(95 \% \mathrm{Cl})$ & & 24103 & & 80025 & $100.0 \%$ & $1.36[1.25,1.49]$ & & \\
\hline Total events & 711 & & 1723 & & & & & \\
\hline $\begin{array}{l}\text { Heterogeneity: Tau }{ }^{2}= \\
\text { Test for overall effect: }\end{array}$ & $\begin{array}{l}0.00 ; \mathrm{Chi}^{\circ} \\
\mathrm{z}=6.85(\end{array}$ & $\begin{array}{l}=0.41, d t \\
b 0.0000\end{array}$ & $\begin{array}{l}\text { if }=3(P= \\
01)\end{array}$ & $=0.94) ; 1^{2}$ & & & $\begin{array}{cc}0.5 & 0.7 \\
\text { Favours [Control] }\end{array}$ & $\begin{array}{cc}1.5 & 2 \\
\text { avours [SHS Exposure] }\end{array}$ \\
\hline
\end{tabular}

FIGURE 4. Forest plot analysis

\section{DISCUSSION}

The present study used a comprehensive search strategy to yield the most related result from different databases and incorporated the available epidemiologic evidence to explore the relationship between SHS exposure and ASD in children. However, only four observational studies fulfilled the inclusion criteria. The overall results suggested a significant association between SHS exposure and ASD risk in children (pooled OR: 1.36, 95\% CI;1.25-1.49). Even though the four studies had different study designs ( 2 cross-sectional, 1 case-control, and 1 mixed study design), there was homogeneity 
within the studies $\left(\mathrm{Chi}^{2}=0.41, \mathrm{p}\right.$-value $\left.=0.94\right)$ and $\mathrm{I}^{2}$ for heterogeneity was $0 \%$. Thus, subgroup and sensitivity analysis were not explored.

The meta-analysis finding was in concordance with several hypotheses of association between SHS exposure and ASD in children. Autism spectrum disorders are considered as multifactorial disorders that arise from an interaction between genetics and environmental factors (Modabbernia et al. 2017). Nicotine, among the thousands of ingredients of tobacco smoke, is the chemical with the highest likelihood to adversely affect brain development (Tiesler \& Heinrich 2014). Its effect was thought to occur via its actions at nicotinic acetylcholine receptors, which mediate neural structural changes. These changes predispose to cognitive, behavioural, and developmental disorders and reduce IQ scores (Kabir et al. 2011). In a review, Eskenazi and Castorina (1999) reported adverse neurocognitive development in children exposed to postnatal SHS exposure as compared to those exposed only during the prenatal period.

Despite significant findings in the pooled odds ratio, there are several general limitations applicable to this meta-analysis that deserve consideration. The number of studies exploring this association is scarce, with only three published studies in five years (Kaur 2014; Khalil et al. 2018; Kim et al. 2018). Most of the available studies examined the association of ASD with smoking exposure during pregnancy with four previous meta-analyses published within 10 years (Gardener et al. 2009; Jung et al. 2017; Rosen et al. 2015; Tang et al. 2015). More studies are needed from different countries and populations to establish an immense amount of epidemiological evidence on the relationship between SHS exposure and ASD in children. The association should be able to be replicated in several studies of the same design or use different epidemiological approaches. As $80 \%$ of smokers worldwide live in lowand middle-income countries (NCI \& WHO 2016) and the prevalence of ASD in these countries is so far unknown (WHO 2017), this will be the area of interest for future research to estimate the true strength of the association and to represent a causal relationship rather than isolated observation from single studies.

Besides that, the study design included in the metaanalysis was mainly cross-sectional and case-control design. The type of study design is another important factor indicating the strength of evidence. Cohort study design which has a higher strength of evidence was not found. There were certain cases where a study that used a relatively weak design can trump a study that had a more robust study design (Evans 2003; Mann 2003; Song \& Chung 2010) with the assumption that the studies were done correctly using controls, randomization, and other factors that were appropriate for that particular type of study; cohort study design remains as the design that has stronger causality explanation as compared to cross- sectional and case-control study. Thus, more cohort and case-control studies with a large sample size should be conducted to ensure robust and high quality of evidences.

Moreover, in all of the analyzed studies, data on exposure to tobacco smoke in children were collected from self-reporting rather than using a biomarker except in a study by Kim et al. (2018), where urine cotinine was used to quantify exposure. Biomarker is a more objective measurement of exposure whereas selfreporting is subject to recall bias and fraud (Coughlin 1990; Hassan 2006; Northrup 1997). Nowadays, noninvasive procedures are available to measure tobacco smoke exposure accurately in children such as using urine, saliva, hair, or nail (Al-Delaimy et al. 2002a, 2002b; Benowitz et al. 2009; Chang et al. 2017). Accurate measurement of tobacco smoke exposure via biochemically confirmed test is important to quantify amount of exposure associated with ASD. In addition, the diagnosis of ASD in children may take a few years since birth to be identified (Charman \& Baird 2002; Filipek et al. 2000; Howlin \& Asgharian 1999) and exposure to tobacco smoke may not be constant throughout life. Some may have had early exposure as early as birth and a constant or later reduced exposure due to smoking cessation by parents or caretakers, but some may have slightly later exposure to tobacco smoke. Thus, timing of exposure assessment is the most crucial element in conducting robust and high-quality studies that can minimize bias.

Apart from that, measurement of outcome, which is the diagnosis of ASD was based on parent self-report in the questionnaire except in Kim et al. (2018), which used the Autism Spectrum Screening Questionnaire (ASSQ) tool that had been validated for initial screening and the diagnosis was confirmed by a psychiatrist. Even though the parent self-report in ASD was previously diagnosed by a medical practitioner, mild spectrum of autism may not be screened, rendering it undetected. Confirmation of diagnosis by a certified individual such as a medical officer and psychiatrist according to DSM-V (APA 2013) could reduce the risk of detection bias.

\section{CONCLUSION}

This meta-analysis indicated that there is a significant association between SHS exposure and risk of ASD among children. Due to the limited number of studies included in the analysis, the current finding should be confirmed through more studies using a robust method, including prospective cohort studies.

\section{ACKNOWLEDGEMENTS}

The authors would like to thank the Universiti Kebangsaan Malaysia for sponsoring this work to be 
published in an open access journal. F.H.J designed the study, F.H.J, N.E.M, M.S.A.M, and S.D.I performed data collection, wrote, and edited the manuscript. F.H.J performed data analysis. Z.M.I provided crucial suggestions for analysis and reviewed the manuscript. The authors declare no conflict of interest. Authors received no specific funding.

\section{REFERENCES}

Abrahams, B.S. \& Geschwind, D.H. 2010. Connecting genes to brain in the autism spectrum disorders. Arch. Neurol. 67(4): 395-399.

Al-Delaimy, W.K., Crane, J. \& Woodward, A. 2002a. Is the hair nicotine level a more accurate biomarker of environmental tobacco smoke exposure than urine cotinine? Journal of Epidemiology \& Community Health 56(1): 66-71.

Al-Delaimy, W.K., Mahoney, G.N., Speizer, F.E. \& Willett, W.C. 2002b. Toenail nicotine levels as a biomarker of tobacco smoke exposure. Cancer Epidemiology and Prevention Biomarkers 11(11): 1400-1404.

ALA. 2016. What's in a Cigarette? American Lung Association. Accessed on 10 November 2018.

APA. 2013. American Psychiatric Association Diagnostic and Statistical Manual of Mental Disorders (Dsm-5®). Washington: American Psychiatric Pub.

Baio, J., Wiggins, L., Christensen, D.L., Maenner, M.J., Daniels, J., Warren, Z., Kurzius-Spencer, M., Zahorodny, W., Rosenberg, C.R., White, T. \& Durkin, M.S., 2018. Prevalence of autism spectrum disorder among children aged 8 years-autism and developmental disabilities monitoring network, 11 sites, United States, 2014. MMWR Surveillance Summaries 67(6): 1-23.

Barnevik-Olsson, M., Gillberg, C. \& Fernell, E. 2010. Prevalence of autism in children of Somali origin living in Stockholm: Brief report of an at-risk population. Developmental Medicine \& Child Neurology 52(12): 11671168.

Benowitz, N.L., Hukkanen, J. \& Jacob, P. 2009. Nicotine chemistry, metabolism, kinetics and biomarkers. Nicotine Psychopharmacology 192: 29-60.

Blaurock-Busch, E., Amin, O.R. \& Rabah, T. 2011. Heavy metals and trace elements in hair and urine of a sample of arab children with autistic spectrum disorder. Maedica 6(4): 247-257.

Chang, C.M., Edwards, S.H., Arab, A., Del Valle-Pinero, A.Y., Yang, L. \& Hatsukami, D.K. 2017. Biomarkers of tobacco exposure: Summary of an FDA-sponsored public workshop. Cancer Epidemiology and Prevention Biomarkers 26(3) 291-302.

Charman, T. \& Baird, G. 2002. Practitioner review: Diagnosis of autism spectrum disorder in 2-and 3-year-old children. Journal of Child Psychology and Psychiatry 43(3): 289-305.

Chastang, J., Baïz, N., Cadwalladder, J.S., Robert, S., Dywer, J., Charpin, D.A., Caillaud, D., De Blay, F., Raherison, C. \& Lavaud, F. 2015. Postnatal environmental tobacco smoke exposure related to behavioral problems in children. PloS ONE 10(8): e0133604.
Chaste, P. \& Leboyer, M. 2012. Autism risk factors: Genes, environment, and gene-environment interactions. Dialogues in Clinical Neuroscience 14(3): 281-292.

Christensen, D.L., Braun, K.V.N., Baio, J., Bilder, D., Charles, J., Constantino, J.N., Daniels, J., Durkin, M.S., Fitzgerald, R.T., Kurzius-Spencer, M. \& Lee, L.C. 2018. Prevalence and characteristics of autism spectrum disorder among children aged 8 years-autism and developmental disabilities monitoring network, 11 sites, United States, 2012. MMWR Surveillance Summaries 65(13): 1-8.

Copeland, J.N. 2018. What is Autism Spectrum Disorder? American Psychiatric Association. Accessed on October 2018 .

Coughlin, S.S. 1990. Recall bias in epidemiologic studies. Journal of Clinical Epidemiology 43(1): 87-91.

Eskenazi, B. \& Castorina, R. 1999. Association of prenatal maternal or postnatal child environmental tobacco smoke exposure and neurodevelopmental and behavioral problems in children. Environmental Health Perspectives 107(12): 991-1000

Evans, D. 2003. Hierarchy of evidence: A framework for ranking evidence evaluating healthcare interventions. Journal of Clinical Nursing 12(1): 77-84.

Filipek, P.A., Accardo, P., Ashwal, S., Baranek, G., Cook, E., Dawson, G., Gordon, B., Gravel, J., Johnson, C. \& Kallen, R. 2000. Practice parameter: Screening and diagnosis of autism: Report of the quality standards subcommittee of the American Academy of Neurology and the Child Neurology Society. Neurology 55(4): 468-479.

Gardener, H., Spiegelman, D. \& Buka, S.L. 2009. Prenatal risk factors for autism: Comprehensive meta-analysis. The British Journal of Psychiatry 195(1): 7-14.

Gospe, S.M., Zhou, S.S. \& Pinkerton, K.E. 1996. Effects of environmental tobacco smoke exposure in utero and/or postnatally on brain development. Pediatric Research 39(3): 494-498.

Grabrucker, A.M. 2013. Environmental factors in autism. Frontiers in Psychiatry 3: 118.

Group, T.G.C. 2006. A cross country comparison of exposure to secondhand smoke among youth. Tobacco Control 15(Suppl 2): ii4-ii19.

Hassan, E. 2006. Recall bias can be a threat to retrospective and prospective research designs. The Internet Journal of Epidemiology 3(2): 339-412.

Health, U.D.O. \& Services, H. 2006. The Health Consequences of Involuntary Exposure to Tobacco Smoke: A Report of the Surgeon General. Atlanta, GA: U.S. Department of Health and Human Services, Centers for Disease Control and Prevention, Coordinating Center for Health Promotion, National Center for Chronic Disease Prevention and Health Promotion, Office on Smoking and Health.

Howlin, P. \& Asgharian, A. 1999. The diagnosis of autism and asperger syndrome: Findings from a survey of 770 families. Developmental Medicine and Child Neurology 41(12): 834-839.

Jarvis, M.J., Sims, M., Gilmore, A. \& Mindell, J. 2012. Impact of smoke-free legislation on children's exposure to secondhand smoke: Cotinine data from the health survey for England. Tobacco Control 21(1): 18-23. 
Jung, Y., Lee, A.M., Mckee, S.A. \& Picciotto, M.R. 2017. Maternal smoking and autism spectrum disorder: Metaanalysis with population smoking metrics as moderators. Scientific Reports 7(1): 4315.

Kabir, Z., Connolly, G.N. \& Alpert, H.R. 2011. Secondhand smoke exposure and neurobehavioral disorders among children in the United States. Pediatrics 128(2): 263-270.

Kalkbrenner, A.E., Schmidt, R.J. \& Penlesky, A.C. 2014. Environmental chemical exposures and autism spectrum disorders: A review of the epidemiological evidence. Current Problems in Pediatric and Adolescent Health Care 44(10): 277-318

Kaur, B. 2014. The Association between Autism Spectrum Disorders and Secondhand Tobacco Exposure. Ohio: Wright State University.

Khalil, N., Kaur, B., Lawson, A., Ebert, J. \& Nahhas, R. 2018. Secondhand smoke exposure is associated with autism spectrum disorder in us males but not in females: Results from the national survey on children's health. Environmental Disease 3(1): 8-17.

Kim, K.M., Lim, M.H., Kwon, H.J., Yoo, S.J., Kim, E.J., Kim, J.W., Ha, M. \& Paik, K.C. 2018. Associations between urinary cotinine and symptoms of attention deficit/hyperactivity disorder and autism spectrum disorder. Environmental Research 166: 481-486.

Kim, Y.S., Leventhal, B.L., Koh, Y.J., Fombonne, E., Laska, E., Lim, E.C., Cheon, K.A., Kim, S.J., Kim, Y.K. \& Lee, H. 2011. Prevalence of autism spectrum disorders in a total population sample. American Journal of Psychiatry 168(9): 904-912.

Landrigan, P.J. 2010. What causes autism? Exploring the environmental contribution. Current Opinion in Pediatrics 22(2): 219-225.

Larsson, M., Weiss, B., Janson, S., Sundell, J. \& Bornehag, C.G. 2009. Associations between indoor environmental factors and parental-reported autistic spectrum disorders in children 6-8 years of age. Neurotoxicology 30(5): 822-831.

Mann, C. 2003. Observational research methods. Research design II: Cohort, cross sectional, and case-control studies. Emergency Medicine Journal 20(1): 54-60.

Matson, J.L. \& Kozlowski, A.M. 2011. The increasing prevalence of autism spectrum disorders. Research in Autism Spectrum Disorders 5(1): 418-425.

Mbulo, L., Palipudi, K.M., Andes, L., Morton, J., Bashir, R., Fouad, H., Ramanandraibe, N., Caixeta, R., Dias, R.C. \& Wijnhoven, T.M. 2016. Secondhand smoke exposure at home among one billion children in 21 countries: Findings from the global adult tobacco survey (GATS). Tobacco Control 25(e2): e95-e100.

Modabbernia, A., Velthorst, E. \& Reichenberg, A. 2017. Environmental risk factors for autism: An evidence-based review of systematic reviews and meta-analyses. Molecular Autism 8(1): 13.

Modesti, P.A., Reboldi, G., Cappuccio, F.P., Agyemang, C., Remuzzi, G., Rapi, S., Perruolo, E. \& Parati, G. 2016. Panethnic differences in blood pressure in Europe: A systematic review and meta-analysis. PloS ONE 11(1): e0147601.

Mohamed, N.N., Loy, S.L., Lim, P.Y., Al Mamun, A. \& Mohamed, H.J.J. 2018. Early life secondhand smoke exposure assessed by hair nicotine biomarker may reduce children's neurodevelopment at 2 years of age. Science of The Total Environment 610: 147-153.

Moher, D., Liberati, A., Tetzlaff, J. \& Altman, D.G. 2009. Preferred reporting items for systematic reviews and metaanalyses: The prisma statement. Annals of Internal Medicine 151(4): 264-269.

NCI \& WHO. 2016. The Economics of Tobacco and Tobacco Control. Geneva: U.S National Cancer Institute and World Health Organization.

Northrup, D.A. 1997. The Problem of the Self-Report in Survey Research. Institute for Social Research, York University.

Öberg, M., Jaakkola, M.S., Woodward, A., Peruga, A. \& Prüss-Ustün, A. 2011. Worldwide burden of disease from exposure to second-hand smoke: A retrospective analysis of data from 192 countries. The Lancet 377(9760): 139-146.

Physicians, R.C.O. 2010. Passive Smoking and Children. London: Tobacco Advisory Group of the Royal College of Physicians.

Pinborough-Zimmerman, J., Bakian, A.V., Fombonne, E., Bilder, D., Taylor, J. \& Mcmahon, W.M. 2012. Changes in the administrative prevalence of autism spectrum disorders: Contribution of special education and health from 2002 2008. Journal of Autism and Developmental Disorders 42(4): 521-530

Rebagliato, M., Bol, F., Florey, C.D.V., Jarvis, M.J., Pérez-Hoyos, S., Hern, I. \& Avi, M.J. 1998. Variations in cotinine levels in smokers during and after pregnancy. American Journal of Obstetrics and Gynecology 178(3): 568-571.

Rice, D. \& Barone Jr., S. 2000. Critical periods of vulnerability for the developing nervous system: Evidence from humans and animal models. Environmental Health Perspectives 108(suppl 3): 511-533.

Rosen, B.N., Lee, B.K., Lee, N.L., Yang, Y. \& Burstyn, I. 2015. Maternal smoking and autism spectrum disorder: A metaanalysis. Journal of Autism and Developmental Disorders 45(6): 1689-1698.

Samadi, S.A., Mahmoodizadeh, A. \& Mcconkey, R. 2012. A national study of the prevalence of autism among five-yearold children in Iran. Autism 16(1): 5-14.

Song, J.W. \& Chung, K.C. 2010. Observational studies: Cohort and case-control studies. Plastic and Reconstructive Surgery 126(6): 2234-2242.

Stang, A. 2010. Critical evaluation of the Newcastle-Ottawa scale for the assessment of the quality of nonrandomized studies in meta-analyses. European Journal of Epidemiology 25(9): 603-605.

Sun, X., Allison, C., Matthews, F.E., Sharp, S.J., Auyeung, B., Baron-Cohen, S. \& Brayne, C. 2013. Prevalence of autism in Mainland China, Hong Kong and Taiwan: A systematic review and meta-analysis. Molecular Autism 4(1): 7.

Symeonides, C., Ponsonby, A.L., Vuillermin, P., Anderson, V. \& Sly, P. 2013. Environmental chemical contributions to adhd and the externalising disorders of childhood-a review of epidemiological evidence. J. Environ. Immunol. Toxicol. 1(2): 92-104.

Tang, S., Wang, Y., Gong, X. \& Wang, G. 2015. A metaanalysis of maternal smoking during pregnancy and autism spectrum disorder risk in offspring. International Journal of Environmental Research and Public Health 12(9): 1041810431. 
Tiesler, C.M., Chen, C.M., Sausenthaler, S., Herbarth, O., Lehmann, I., Schaaf, B., Krämer, U., Von Berg, A., Von Kries, R. \& Wichmann, H.E. 2011. Passive smoking and behavioural problems in children: Results from the lisaplus prospective birth cohort study. Environmental Research 111(8): 1173-1179.

Tiesler, C.M. \& Heinrich, J. 2014. Prenatal nicotine exposure and child behavioural problems. European Child \& Adolescent Psychiatry 23(10): 913-929.

WHO. 2017. Autism Spectrum Disorders. Geneva: World Health Organization. Accessed on 10 November 2018.

Yolton, K., Dietrich, K., Auinger, P., Lanphear, B.P. \& Hornung, R. 2004. Exposure to environmental tobacco smoke and cognitive abilities among us children and adolescents. Environmental Health Perspectives 113(1): 98-103.
Department of Community Health

Universiti Kebangsaan Malaysia Medical Centre 56000 Cheras, Kuala Lumpur, Wilayah Persekutuan Malaysia

*Corresponding author; email: zms@ppukm.ukm.edu.my

Received: 19 May 2019

Accepted: 11 March 2020 
SUPPLEMENTAL TABLE 1. Quality assessment based on the Ottawa-Newcastle Scale

\begin{tabular}{|c|c|c|c|c|c|c|c|c|c|c|}
\hline $\begin{array}{l}\text { Cross- } \\
\text { Sectional } \\
\text { Study }\end{array}$ & $\begin{array}{l}\text { Representativeness } \\
\text { of the sample }\end{array}$ & Sample size & $\begin{array}{l}\text { Non- } \\
\text { respondents }\end{array}$ & $\begin{array}{l}\text { Ascertainment } \\
\text { of the } \\
\text { exposure* }\end{array}$ & $\begin{array}{l}\text { Comparability } \\
\text { of Cases and } \\
\text { Controls }\end{array}$ & $\begin{array}{l}\text { Assessment } \\
\text { of the } \\
\text { outcome* }\end{array}$ & Statistical test & & $\begin{array}{l}\text { Total } \\
\text { Score }\end{array}$ & $\begin{array}{c}\text { Average } \\
\text { Score }\end{array}$ \\
\hline $\begin{array}{l}\text { (Kaur } \\
2014)\end{array}$ & $1^{\mathrm{a} /} 1^{\mathrm{b}}$ & $1^{\mathrm{a}} / 1^{\mathrm{b}}$ & $0^{\mathrm{a} /} 1^{\mathrm{b}}$ & $1^{\mathrm{a}} / 1^{\mathrm{b}}$ & $1^{\mathrm{a}} / 1^{\mathrm{b}}$ & $1^{\mathrm{a}} / 1^{\mathrm{b}}$ & $1^{\mathrm{a}} / 1^{\mathrm{b}}$ & & $6^{\mathrm{a}} / 7^{\mathrm{b}}$ & 6.5 \\
\hline $\begin{array}{l}\text { (Khalil } \\
\text { et al. } \\
2018)\end{array}$ & $1^{\mathrm{a}} / 1^{\mathrm{b}}$ & $1^{\mathrm{a}} / 1^{\mathrm{b}}$ & $1^{\mathrm{a}} / 1^{\mathrm{b}}$ & $1^{\mathrm{a}} / 1^{\mathrm{b}}$ & $1^{\mathrm{a}} / 1^{\mathrm{b}}$ & $1^{\mathrm{a}} / 1^{\mathrm{b}}$ & $1^{\mathrm{a}} / 1^{\mathrm{b}}$ & & $7^{\mathrm{a}} / 7^{\mathrm{b}}$ & 7.0 \\
\hline $\begin{array}{l}\text { Case- } \\
\text { Control } \\
\text { Study }\end{array}$ & Definition of Cases & $\begin{array}{l}\text { Representativeness } \\
\text { of Cases }\end{array}$ & $\begin{array}{l}\text { Selection of } \\
\text { Controls }\end{array}$ & $\begin{array}{l}\text { Definition of } \\
\text { Controls }\end{array}$ & $\begin{array}{l}\text { Comparability } \\
\text { of Cases and } \\
\text { Controls* }\end{array}$ & $\begin{array}{l}\text { Ascertainment } \\
\text { of Exposure }\end{array}$ & $\begin{array}{l}\text { Ascertainment } \\
\text { for Cases and } \\
\text { Controls }\end{array}$ & $\begin{array}{l}\text { Non- } \\
\text { Response } \\
\text { Rate }\end{array}$ & & \\
\hline $\begin{array}{l}\text { (Kim et } \\
\text { al. 2018) }\end{array}$ & $1^{\mathrm{a}} / 1^{\mathrm{b}}$ & $1^{\mathrm{a} /} / 1^{\mathrm{b}}$ & $1^{\mathrm{a} /} / 1^{\mathrm{b}}$ & $1^{\mathrm{a}} / 1^{\mathrm{b}}$ & $2^{\mathrm{a}} / 2^{\mathrm{b}}$ & $1^{\mathrm{a} /} 1^{\mathrm{b}}$ & $1^{\mathrm{a}} / 1^{\mathrm{b}}$ & $1^{\mathrm{a}} / 1^{\mathrm{b}}$ & $9^{\mathrm{a}} / 9^{\mathrm{b}}$ & 9.0 \\
\hline $\begin{array}{l}\text { Cohort } \\
\text { Study }\end{array}$ & $\begin{array}{l}\text { Representativeness } \\
\text { of the exposed } \\
\text { cohort }\end{array}$ & $\begin{array}{l}\text { Selection of the } \\
\text { non-exposed } \\
\text { cohort }\end{array}$ & $\begin{array}{l}\text { Ascertainment } \\
\text { of exposure }\end{array}$ & $\begin{array}{l}\text { Outcome not } \\
\text { present at start }\end{array}$ & $\begin{array}{l}\text { Comparability } \\
\text { of cohorts* }\end{array}$ & $\begin{array}{l}\text { Assessment of } \\
\text { outcome }\end{array}$ & $\begin{array}{l}\text { Duration of } \\
\text { follow-up }\end{array}$ & $\begin{array}{l}\text { Adequacy } \\
\text { of } \\
\text { follow-up }\end{array}$ & & \\
\hline $\begin{array}{l}\text { (Larsson } \\
\text { et al. } \\
\text { 2009) }\end{array}$ & $1^{\mathrm{a} /} 1^{\mathrm{b}}$ & $1^{\mathrm{a} /} / 1^{\mathrm{b}}$ & $1^{\mathrm{a}} / 0^{\mathrm{b}}$ & $0^{\mathrm{a}} / 0^{\mathrm{b}}$ & $2^{\mathrm{a}} / 2^{\mathrm{b}}$ & $0^{\mathrm{a}} / 0^{\mathrm{b}}$ & $1^{\mathrm{a}} / 1^{\mathrm{b}}$ & $0^{\mathrm{a}} / 0^{\mathrm{b}}$ & $6^{\mathrm{a}} / 5^{\mathrm{b}}$ & 5.5 \\
\hline
\end{tabular}

*A maximum of 2 points were assigned to this item., ${ }^{\text {a }}$ Score given by 1 st author, ${ }^{\mathrm{b}}$ Score given by 2 nd author 